\title{
Conducted Interference Immunity Characteristics to High-speed Power Line Communication System
}

\author{
Masamitsu Tokuda Member (Tokyo City University) \\ Satoshi Hosoya Non-member (Tokyo City University) \\ Toru Yamagata Non-member (Tokyo City University) \\ Takashi Matsuo Non-member (Sumitomo Electric Networks, Inc.)
}

Keywords : Power Line Communication (PLC), OFDM, Notch, Immunity, Narrowband conducted interference

Recently, the Internet spreads rapidly, and the demand of the home network to connect various electronic equipments in a home has risen. As one of the means to build this home network, PLC (Power Line Communication) is provided recently. PLC is a method to communicate each other by using a power line installed to supply electricity as transmission channel, and high-speed communication is enabled by using a high frequency band $(2-30 \mathrm{MHz})$. However, there are many radio systems using the high frequency band such as radio equipment for a plane and ship, ham radio, which emit strong radio wave, and so it is possible for PLC system to be interfered from their systems. Therefore, it is important to know the immunity characteristics of PLC system to the radio wave.

In this paper, we measured the immunity characteristics to the conducted interference wave, from the aspect of $\mathrm{PHY}$ rate (physical layer date rate) of PLC system, and compared with simulation results by MATLAB/Simulink. Figure 1 show the measurement system of PHY rate, which is set in a shield room. Normally, PLC modem is directly connected to AC power line, but in this case, the measurement system connected to DC power line is provided to suppress the power supply coupling. Sending and receiving PCs are connected through PLC modem and power line model. The communication link between sending and receiving PCs is established and measured PHY rate. The OFDM (Orthogonal Frequency Division Multiplexing) signal wave forms of the PLC modem are detected by using WCA (Wireless Communication Analyzer), and shown in Fig.2, where there are

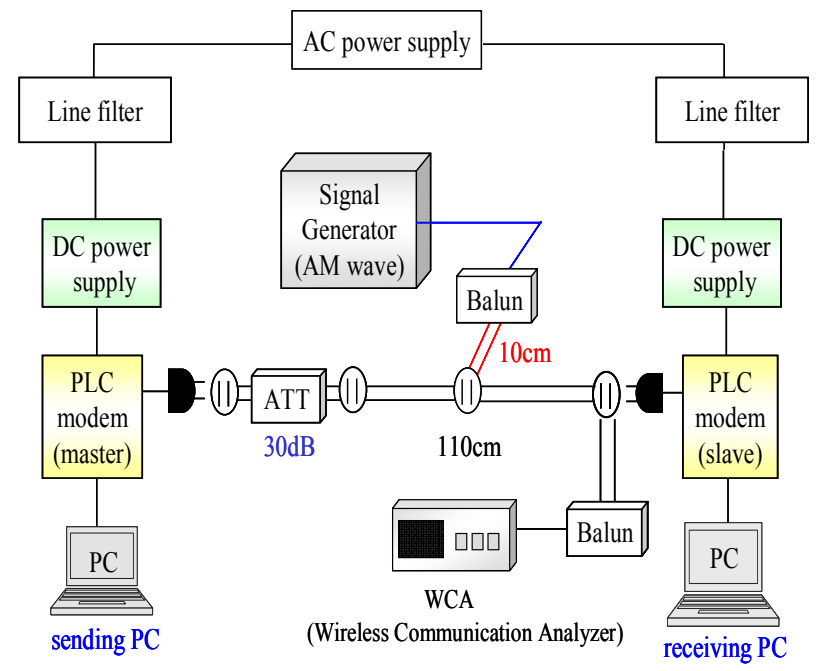

Fig. 1. Measurement system of conducted interference immunity for PLC modem. many notchs and an interference wave with the frequency of $18 \mathrm{MHz}$ is impressed.

Figure 3 shows the relation between C/I (Carrier / Interference) level and the PHY rate normalized by the maximum value, that is the normalized PHY rate, to narrow band interference signal. When the interference signal is impressed to the OFDM signal, the PHY rate decreases rapidly below $\mathrm{C} / \mathrm{I}=25 \mathrm{~dB}$ and become nearly zero around $\mathrm{C} / \mathrm{I}=-35 \mathrm{~dB}$, and so it turns out that the PLC system with OFDM signal has a good narrowband interference immunity characteristic.

In addition, we examined the improving effect of the notch band for the immunity characteristics to the conducted interference wave. As a result, it is revealed that the PHY rate normalized by the maximum value increases by about $15-25 \%$ by inserting the notch when impressing the interference signal in the notch band and $\mathrm{C} / \mathrm{I}$ is improved by $10 \sim 15 \mathrm{~dB}$ by inserting the notch.

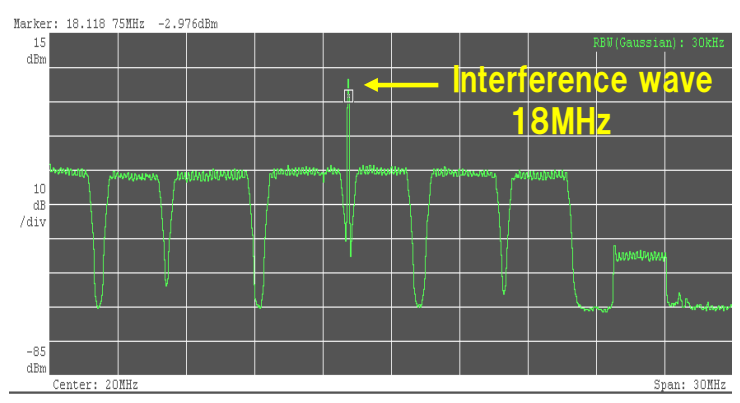

Fig. 2. Frequency spectrum for OFDM signal and conducted interference wave at $18 \mathrm{MHz}$.

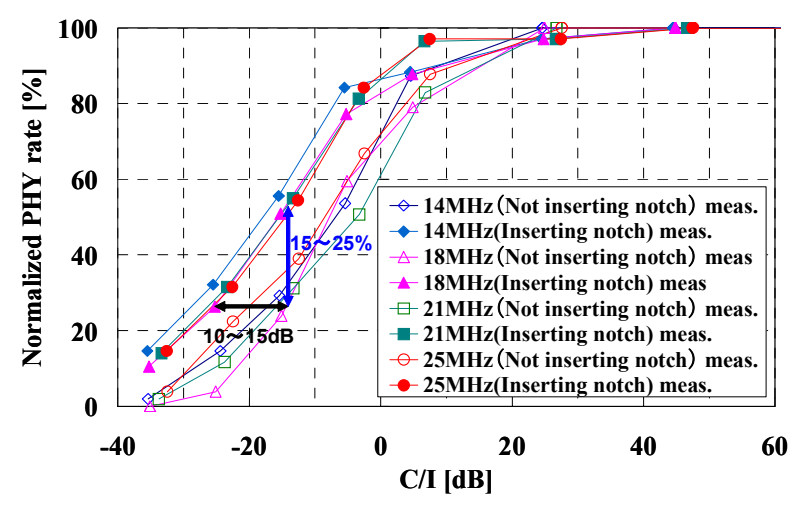

Fig. 3. Comparing inserting notch with not inserting notch for the interference immunity characteristics (Normalized PHY rate). 


\begin{abstract}
高速電力線通信システムの伝導妨害波イミュニティ特性

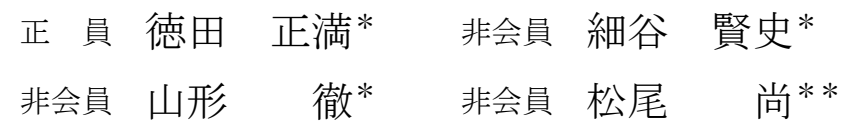

\section{Conducted Interference Immunity Characteristics to High-speed Power Line Communication System}

Masamitsu Tokuda*, Member, Satoshi Hosoya*, Non-member, Toru Yamagata*, Non-member, Takashi Matsuo**, Non-member

In this paper, we measured the immunity characteristics to the conducted interference wave, from the aspect of PHY rate (physical layer data rate) of PLC (Power Line Communication) system, and compared with simulation results by MATLAB/ Simulink. When the interference signal is impressed to the OFDM (Orthogonal Frequency Division Multiplexing) signal, the PHY rate decrease rapidly below $\mathrm{C} / \mathrm{I}($ Carrier $/$ Interference $)=25 \mathrm{~dB}$ and become nearly zero around $\mathrm{C} / \mathrm{I}=-35 \mathrm{~dB}$, and so it turns out that the PLC System with OFDM signal has a good narrowband interference immunity characteristic. In addition, it is revealed that the PHY rate of PLC modem can be calculated by MATLAB/Simulink even when the narrowband interference signal is impressed through the power line. Furthermore, we examined the improving effect of the notch band for the immunity characteristics to the conducted interference wave. As a result, it is revealed that the PHY rate normalized by the maximum value increases by $15 \sim 25 \%$ by inserting the notch when impressing the interference signal in the notch band and $\mathrm{C} / \mathrm{I}$ is improved by
\end{abstract}

論 文 $10 \sim 15 \mathrm{~dB}$ by inserting the notch.

キーワード : 電力線通信 (PLC : Power Line Communication), OFDM, ノッチ, イミュニティ, 狭帯域伝導妨害波

Keywords : Power Line Communication (PLC), OFDM, Notch, Immunity, Narrowband conducted interference

\section{1. まえがき}

近年，インターネット利用者の爆発的増加や家電の IT 化 に伴い，身の周りのあらゆるものが “ユビキタス”、動き 始めており，政府の「u-Japan」の後押しもあって，ますま す加速している。それらの実現手段の一つとして注目され ているのが, 高速の電力線通信 ( PLC: Power Line Communication）である。電力線は既に電力を供給するため に敷設されているので，敷設コストが不要となる。また， 電力と情報の同時供給を 1 つのプラグで行えるため，ホー ムネットワークの手段として大きく期待されている。

PLC は商用電力を供給するために敷設された家庭内の電 力線に, 通信信号を重畳することにより通信線として用い るが， 2002 年頃は $450 \mathrm{kHz}$ 以下の周波数を使用する PLC シ ステムが国内では認められていた ${ }^{(1)}$ 。その後, $2 \mathrm{MHz} \sim 30 \mathrm{MHz}$ の短波帯を使用する高速 PLC に関する検討が盛んになり，

* 東京都市大学

干158-8557 東京都世田谷区玉堤 1-28-1

Tokyo City University

1-28-1, Tamazutsumi, Setagaya-ku, Tokyo 158-8557

** 住友電工ネットワークス（株）

干141-0022 東京都品川区東五反田 3-20-14

Sumitomo Electric Networks, Inc.

3-20-14, Takanawa Park Tower, Higashi-gotanda, Shinagawa-ku, Tokyo 141-0022
米国の HPA (Home Plug Power Line Alliance) などが先行して いた ${ }^{(2)}$ 。日本でも，2003 年に高速電力線通信推進協議会 (PLC-J) が発足し ${ }^{(3)}$, 数百 Mbps の高速データ伝送が可能な 高速 PLC モデムに関する実証実験が行われた ${ }^{(4)}$ (9)。その成 果を基にして PLC-J が総務省に働きかけたところ, 高速 PLC に関する研究会が 2005 年に発足し ${ }^{(10)}, 2006$ 年 10 月に市場 導入が認められ，各種の高速 PLC モデムが販売されるよう になった ${ }^{(11)(12)}$ 。

高速 PLC の伝送媒体である家庭内の電力線はバス配線に なっており, 多種多様な機器が接続されるため, 電力線の インピーダンス, 伝送路損失, 雑音レベルが大きく変動す るほか，信号の反射や分散など電力線特有の問題がある。 この問題を克服するため, 最近各種の通信分野で注目され ているマルチキャリア方式の OFDM (Orthogonal Frequency Division Multiplexing : 直交周波数分割多重）技術が採用され ている。OFDM 方式では複数のサブキャリアを利用するこ とにより, 電力線の伝送路状態に柔軟に追従できるととも に, 周波数領域の各サブキャリアの直交性により周波数利 用効率の高い伝送が可能となる。また, 既存無線システム の存在する帯域の送信レベルを容易に制御できるため, 現 在開発中の高速 PLC モデムの変調方式として主流となって いる。 
このような背景の中, OFDM 方式で構成された高速 PLC モデムを用いた実環境実験が行なわれており，漏洩電波低 減技術に関する研究報告や，分岐を有するモデルの伝送特 性に関する検討がなされている(13) (18)。しかし, 高速 PLC は 2〜30MHz の周波数帯域を利用して通信を行うが，この 周波数帯域には航空機, 船舶, アマチュア無線, 短波放送 など多くの短波通信が存在する。このような短波通信への 電波干渉を防ぐために, 高速 PLC モデムの OFDM 信号にお いて，当該サブキャリアを使用しないようにしたノッチ技 術がある。高速 PLC の実用化と普及を目指している PLC-J では，高速 PLC モデムにあらかじめノッチを挿入するよう にガイドラインで規定している ${ }^{(3)}$ 。

一方，上記短波通信の送信機から放射された電波が逆に 高速 PLC の伝送特性に影響を及ぼして, 伝送速度が低下し, 最悪の場合は誤動作の発生することが懸念される。短波通 信の場合は，波長が長いため，PLC モデムに電波で直接影 響を及ぼすよりも，短波通信送信機の放射電波が電力線に 誘導されて伝導妨害波として PLC モデムに侵入し，影響を 及ぼす場合が多いと考えられる。このような伝導妨害波が 高速 PLC モデムに侵入してきたときに, 短波通信への電波 干渉防止用に検討されているノッチ技術が, どのように作 用するかを検討した例は存在しない。一方，このような伝 導妨害波によって一般の電気電子機器が誤動作しないよう にするために, IEC（国際電気標準会議）の TC77（第 77 専 門委員会: EMC (Electromagnetic Compatibility : 電磁両立性) 規格の作成を担当）では，「無線周波電磁界で誘導された伝 導妨害に対するイミュニティ試験規格 IEC 61000-4-6」を作 成している(19)(20)。

本論文では，短波通信送信機から放射された電波が電力 線に誘導した伝導妨害波に対する高速 PLC モデムのイミュ ニティ特性, 特に, ノッチによるイミュニティ改善効果を 把握することを目的として，実際に高速 PLC モデムに IEC 61000-4-6 で規定された狭帯域伝導妨害波を印加して PHY rate (Physical layer data rate) を測定している。また, MATLAB/Simulink を用いたシミュレーションにより，測定 と同様に狭帯域伝導妨害波に対する PHY rate を計算してい る。

\section{PLC モデムの伝導妨害波イミュニティ測定}

〈2・1〉 伝導妨害波イミュニティの測定法 高速 PLC モデムの伝導妨害波に対するイミュニティ測定系を図 1 に 示す。PLC モデム master から送出された信号は, 家庭内の 電力線の平均的な減衰を模擬した $30 \mathrm{~dB}$ 減衰器 (ATT: Attenuator）を通り，その後，長さ $110 \mathrm{~cm}$, 導体直径 $1.6 \mathrm{~mm}$ の 2 芯 VVF (Vinyl insulated and Vinyl sheathed Flat type) から なる電力線を通り, PLC モデム slave に到達する。この PLC モデムの伝送信号に対して, IEC 61000-4-6 で規定された振 幅変調波（変調度 $80 \%$ ・被変調周波数 $1 \mathrm{kHz}$ ） からなる伝導 妨害波を印加するが，その伝導妨害波は信号発生器（Signal Generator）で発生させ，バラン（Balun）を介して電力線と

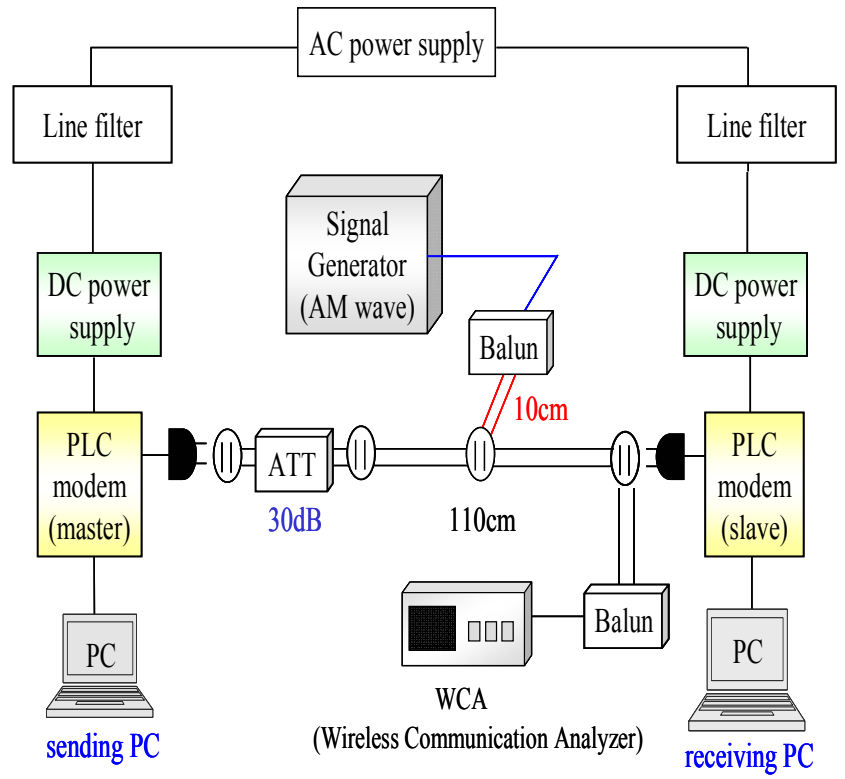

図 1 PLC モデムの伝導妨害波イミュニティ測定系

Fig. 1. Measurement system of conducted interference immunity for PLC modem.

結合している。バランを挿入したのは, 被測定ケーブルで ある電力線は平衡ケーブルあるのに対して, 信号発生器の 出力は同軸ケーブルで構成されているため, 同軸の不平衡 型から電力線の平衡型に変換するためである。バランの機 種としては, イーサネット用のバラン (BH040-0092: BH-Electronics 社製) を使用した。バランの電力線から見た

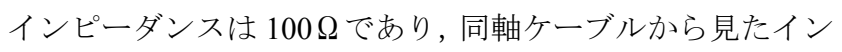
ピーダンスは $50 \Omega$ である。高速 PLC モデムや伝導妨害波の 周波数スペクトルを観測するため, ソニーテクトロニクス 社製の WCA (Wireless Communication Analyzer: SONY Tektronix WCA380) を用いた。この場合も電力線に接続する 場合はバランを用いたが, バランの電力線から見たインピ ーダンスは $100 \Omega$ であり, また, 高速 PLC モデムの入出力 インピーダンスは $100 \Omega$ のため, 電力線の特性インピーダン ス約 $100 \Omega$ から見ると半分の約 $50 \Omega$ のンピーダンスにな り, インピーダンス不整合が発生している。しかし, バラ ンの電力線は $10 \mathrm{~cm}$ 以下になるようにしており, また, 高速 PLCモデムからの電力線も $10 \mathrm{~cm}$ 以下になるようにしている ため, 測定最高周波数 $35 \mathrm{MHz}$ の波長 $8.6 \mathrm{~m}$ から考えると, WCA の観測波形は高速 PLC モデムの受信部の波形を観測 しているものと見なせる。もし, 若干の誤差が生じても, 後述するように, 全てのサブキャリアの全電力レベル C (Carrier) と狭帯域妨害波の電力レベル I（Interference）を同 じWCA で測定し, それらの比 C/I (Carrier/Interference) で 妨害波の程度を評価するため, 問題ないと判断する。

PLC モデムの伝導妨害波に対するイミュニティを評価す るための伝送特性として, PHY rate を用いている。PHY rate とは, 物理層の伝送速度を意味し, モデムの通信方式と伝 送媒体によって決定される理想的な伝送速度を表してい る。ここでは, 住友電気工業株式会社製の高速 PLC モデム 
表 1 使用した PLC モデムのパラメータ

Table 1. Measurement parameter of PLC modem used.

\begin{tabular}{|c|c|}
\hline Item & Specification \\
\hline Frequency range & $2-34 \mathrm{MHz}$ \\
\hline Bandwidth & $30 \mathrm{MHz}$ (Max.) \\
\hline Data rate (Physical level) & $200 \mathrm{Mbps}$ (Max.) \\
\hline Modulation & OFDM \\
\hline Number of sub-carrier & About 1500 \\
\hline Transmission Power & $-50 \mathrm{dBm} / \mathrm{Hz}$ (Max.) \\
\hline
\end{tabular}

試作器を用いて, OFDM 信号に対する PHY rate を測定した。 なお，使用した高速 PLC モデムについて公開されているパ ラメータを表 1 に示す。OFDM 信号のサブキャリア数は約 1500 で，2３0MHz の周波数帯域に配置されている。PHY rate は,ノッチを挿入しない状態で, 最大 $200 \mathrm{Mbps}$ を出す ことが可能である。

この高速 PLC モデム試作器は，ソフトによりノッチを挿 入できるため（ノッチの周波数と帯域幅はあらかじめ設定 されている)，ノッチを挿入した前後の PHY rate を測定し た。高速 PLC モデムの PHY rate は, PLC モデム試作器にセ ットされている専用ソフトで測定した。高速 PLC モデムに 接続された送信側 PC と受信側 PC の間でping の送受信を行 い，モデムを介した PC 間での通信リンクを確立した上で, 送信側 PC から親モデムにアクセスして PHY rate を測定し た。

市販されている高速 PLC モデムは, AC 電力が供給され ている電力線に接続して, 電力の供給と信号伝送の両方を 行っているが, 図 1 の測定系では, DC 電源を介して高速 PLC モデムに電力を供給しており, 電力線モデルには $\mathrm{AC}$ 電源を 供給せずに，通信信号のみを伝送させている。ここで使用 した高速 PLC モデム試作器では, AC 電力供給の他に DC 電 力供給も可能になっており, 伝導妨害波印加用信号発生器 や信号波形観測用測定器の保護, 測定者の安全性などを考 慮して, DC 電力供給を使用した。なお， master と slaveの PLC モデムに DC 電力を供給している DC 電源は，通常の $\mathrm{AC}$ 商用電源から $\mathrm{AC}$ 電力を供給されているが，モデムの通 信信号や伝導妨害波が DC 電源を経由して $\mathrm{AC}$ 商用電源と結 合するのを防止するために， $\mathrm{DC}$ 電源と $\mathrm{AC}$ 商用電源の間に $\mathrm{AC}$ ラインフィルターを挿入している。

\section{〈2·2〉 PLC 信号と伝導妨害波のスペクトル波形}

高速 PLC モデムから送信された OFDM 信号に，「無線周 波電磁界で誘導された伝導妨害に対するイミュニティ試験 規格 IEC 61000-4-6」で規定された狭帯域伝導妨害波（変調 度 $80 \%$ ・被変調周波数 $1 \mathrm{kHz}$ ）を印加した時の周波数スペク トル模式図を図 2 に示す。(a)はノッチを挿入しない状態で あり，(b)はノッチを挿入した状態である。OFDM 信号のサ ブキャリアが $2 \mathrm{MHz}$ から $30 \mathrm{MHz}$ に配置されている。(b)を見 ると，14MHz，18MHz，21MHz および $25 \mathrm{MHz}$ の 4 つの周 波数にノッチが挿入されている。それらのノッチ周波数に 伝導妨害波を印加するとともに，ノッチ周波数の近傍にあ る $22 \mathrm{MHz}$ と $26 \mathrm{MHz}$ にも伝導妨害波を印加している。さら

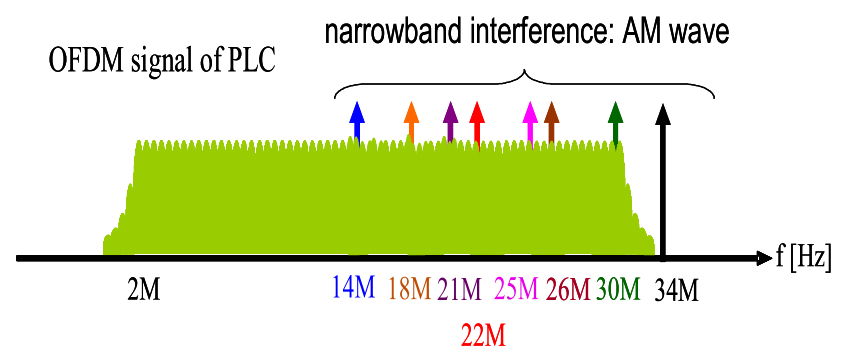

(a) Not inserting notch

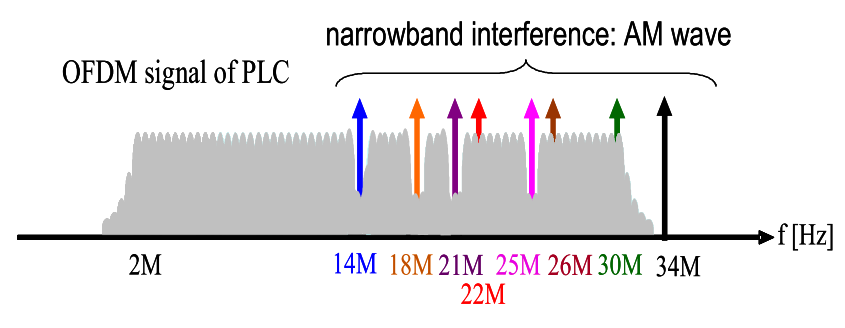

(b) Inserting notch

図 2 OFDM 信号と伝導妨害波の周波数スペクトル模式図 Fig. 2. Pattern diagrams of frequency spectrum for OFDM signal and conducted interference wave.

に, OFDM 信号の高周波境界である $30 \mathrm{MHz}$ とその境界の外 にある $34 \mathrm{MHz}$ でも伝導妨害波を印加して, イミュニティ特 性を測定している。

高速 PLC モデムの OFDM 信号と伝導妨害波をWCA で測 定した結果を図 3 に示す。(a)はノッチを挿入していない状 態であり，(b)はノッチを挿入した状態である。また，(b)の ノッチを挿入した状態に, 伝導妨害波を $18 \mathrm{MHz}$ に印加した 状態を(c)に示している。OFDM 信号のサブキャリア間隔は 表 1 より約 $20 \mathrm{kHz}$ であるが, WCA の周波数分解能最小值が $30 \mathrm{kHz}$ であるため, サブキャリアの電力レベル C を $30 \mathrm{kHz}$ で測定することにした。周波数分解能を $20 \mathrm{kHz}$ で電力レベ ル C を測定した場合より, $30 \mathrm{kHz}$ で測定した電力レベル $\mathrm{C}$ の方が若干大きくなるが, その差は僅かであるため, 問題 ないと考える。一方, 伝導妨害波は変調周波数 $1 \mathrm{kHz}$ の振幅 変調（変調度 $80 \%$ ）のために帯域幅は $2 \mathrm{kHz}$ であるので, WCA の周波数分解能が $30 \mathrm{kHz}$ であれば, 狭帯域伝導妨害波 の電力レベルを正確に測定できる。

〈2·3〉 伝導妨害波に対するサブキャリアの特性

ここで用いた高速 PLC モデムでは, サブキャリアの受信 特性に応じてビットの割付值を制御する適用変調を行って いる。各サブキャリアのビット割付值が妨害波の印加レベ ルによって変化する様子を図 4 に示す。図の縦軸は, ビッ 卜割付值であり, サブキャリアの変調方法に依存して決ま る值である。例えば, BPSK では, ビット割付值は 1 であり， QPSK では 2，16QAM では 4 というように増加していく。

狭帯域妨害波の印加周波数は $21 \mathrm{MHz}$ で, 妨害波の電力レ ベル I と全てのサブキャリアの全電力レベル C との比 $\mathrm{C} / \mathrm{I}$ を変化させた状態のビット割付值特性を図 4 の(a), (b)及び(c) 


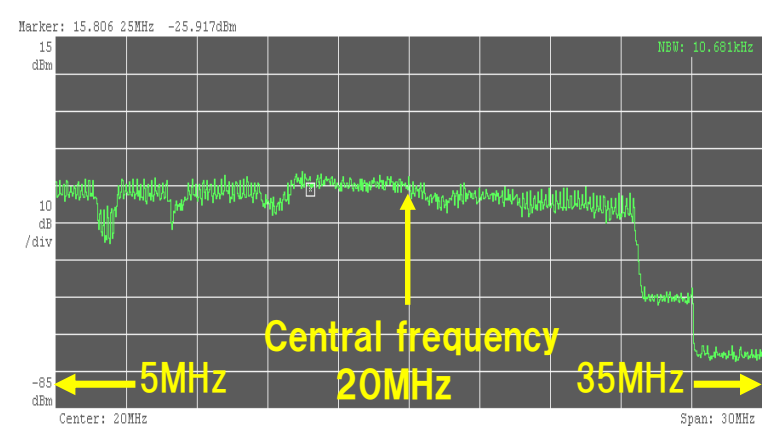

(a) Not inserting notch

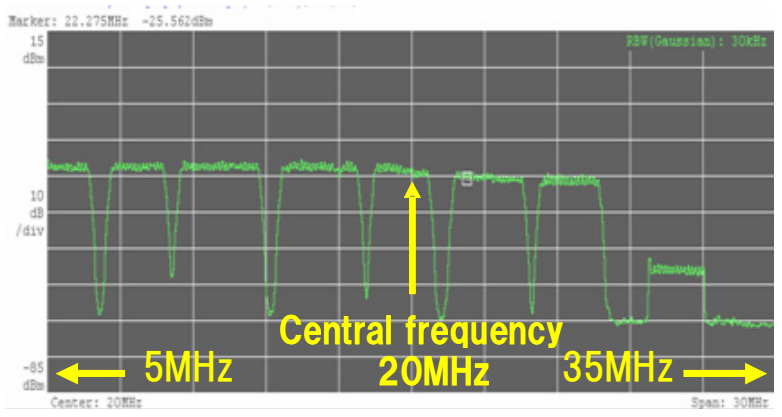

(b) Inserting notch

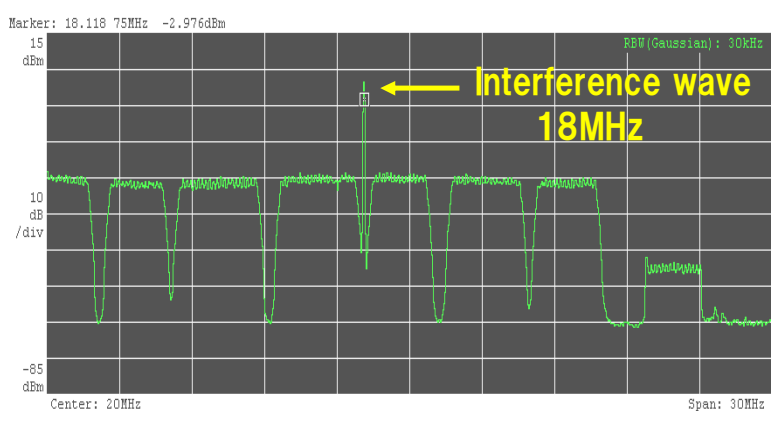

(c) When impressing conducted interference wave at $18 \mathrm{MHz}$

図 3 OFDM 信号と伝導妨害波の周波数スペクトル測定例

Fig.3. Measured examples of frequency spectrum for OFDM signal and conducted interference wave.

に示している。なお, 全てのサブキャリアの全電力レベル C は $30 \mathrm{~dB}$ の減衰器を挿入した状態でー $26.3 \mathrm{dBm}$ ある。困 4(a) の $\mathrm{C} / \mathrm{I}=35 \mathrm{~dB}$ と妨害波のレベルが非常に弱い状態では，印 加周波数 $21 \mathrm{MHz}$ に対応するサブキャリアのみが影響を受け て，ビット割付值が 0 になっており，情報を伝送していな い状態になっている。しかし，それ以外の周波数では，妨 害波の影響を全く受けずに，ビット割付值が 8〜10 の值に なっている。ところが, 図 5(b)の $\mathrm{C} / \mathrm{I}=5 \mathrm{~dB}$ と妨害波のレベ ルが強くなると, 妨害波に近い周波数のサブキャリアほど 妨害波の影響を受け，ビット割付值が 2 や 3 と極端に低下 し, 妨害波の周波数から遠ざかるほじ, 妨害波の影響が小 さくなる。さらに, 図 4(c)の $\mathrm{C} / \mathrm{I}=-25 \mathrm{~dB}$ と妨害波のレベル がさらに強くなると, 妨害波に近い周波数のサブキャリア はほとんど通信できない状態になり，妨害波の周波数から 離れたサブキャリアでも, ビット割付值が 2 や 4 と極端に 低下寸る。ここで, 狭帯域妨害波の周波数に近いサブキャ

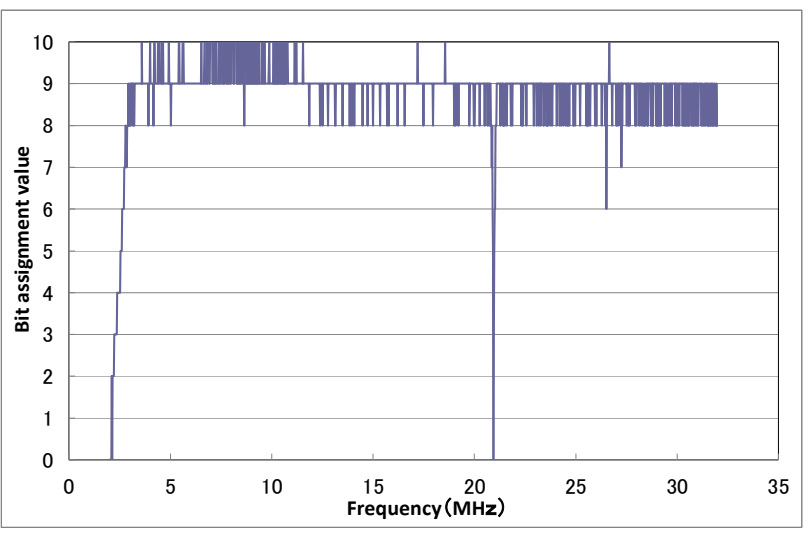

(a) Impressing interference level $\mathrm{C} / \mathrm{I}=35 \mathrm{~dB}$

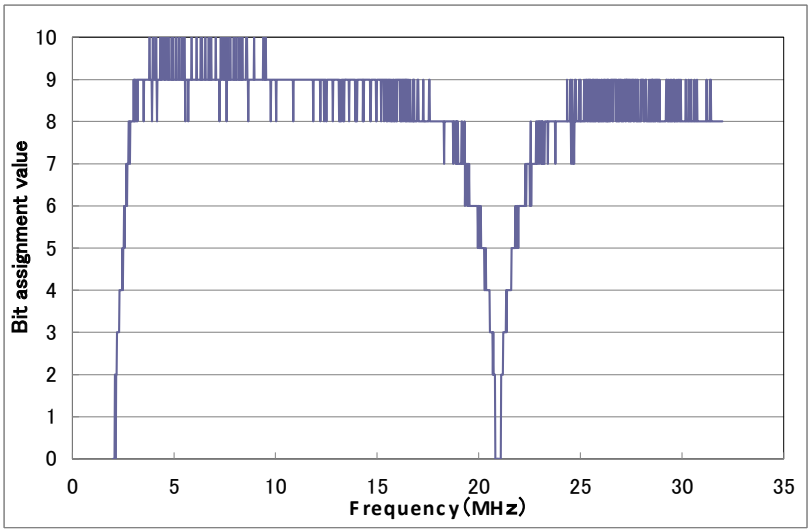

(b) Impressing interference level $\mathrm{C} / \mathrm{I}=5 \mathrm{~dB}$

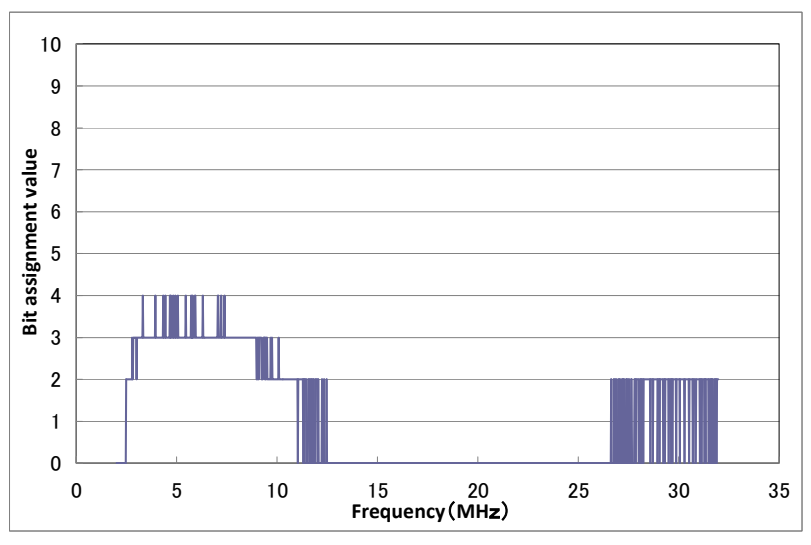

(c) Impressing interference level $\mathrm{C} / \mathrm{I}=-25 \mathrm{~dB}$

図 4 妨害波レベルに対するビット割付特性

(周波数 $21 \mathrm{MHz}$ )

Fig. 4. Bit assignment characteristics to interference level (Frequency 21MHz).

リアほどビット割付值が低下するメカニズムであるが，妨 害波を 1 シンボル時間でフーリエ級数展開した際の各項の エネルギーが, 各サブキャリアへの妨害信号レベルとなり(21), それに応じて, サブキャリア毎に適切なビット割付が行わ れているからである。

図 4 の(a), (b), (c) と妨害波の電力レベルを大きくしてい くとサブキャリアのビット割付值特性が大幅に低下してい くが，この原因として，上記の原因以外に，高速 PLC モデ ムの受信部におけるゲイン自動制御機能が関連している。 


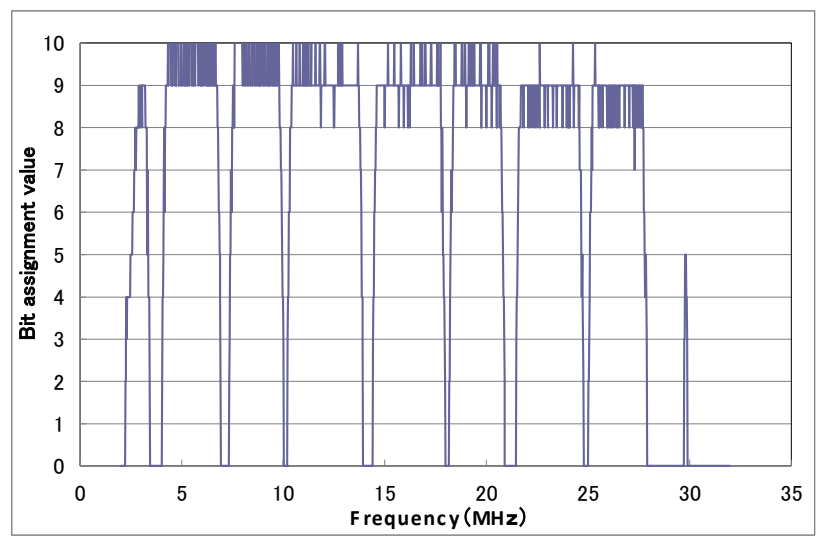

(a) Impressing interference level $\mathrm{C} / \mathrm{I}=35 \mathrm{~dB}$

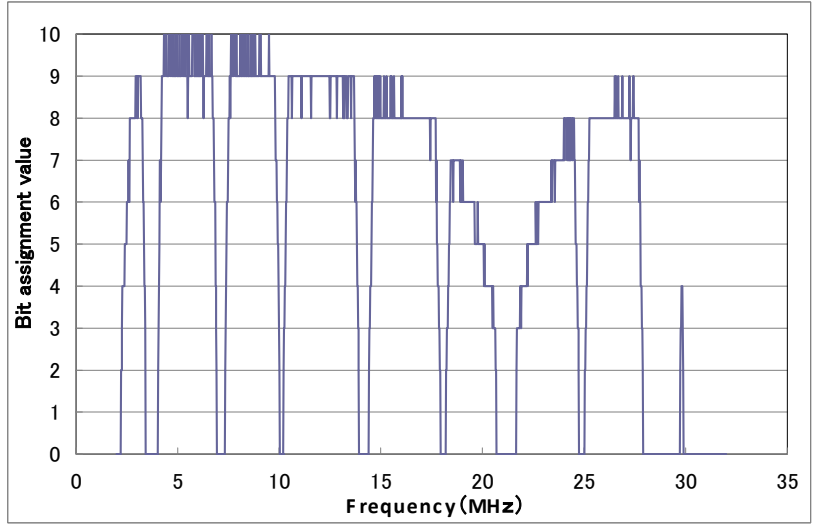

(b) Impressing interference level $\mathrm{C} / \mathrm{I}=5 \mathrm{~dB}$

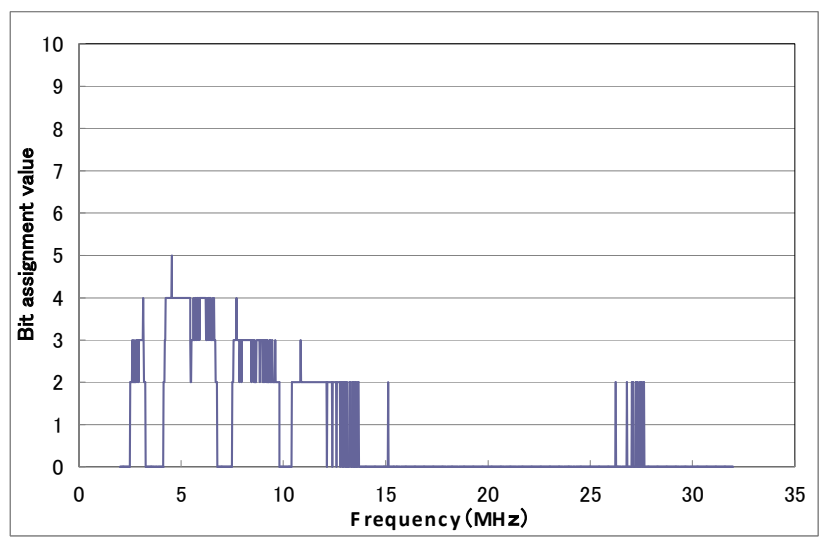

(c) Impressing interference level $\mathrm{C} / \mathrm{I}=-25 \mathrm{~dB}$

図 5 ノッチ挿入状態の妨害波レベルに対するビット 割付特性（周波数 $21 \mathrm{MHz}$ )

Fig. 5. Bit assignment characteristics to interference level when inserting the notch (Frequency $21 \mathrm{MHz}$ ).

妨害波の電力レベルが大きくなると, 受信部の増幅器にお ける飽和を防止するため，ゲインの量を低下させる機能が ある。図 4(a)の $\mathrm{C} / \mathrm{I}=35 \mathrm{~dB}$ では，受信信号を $30 \mathrm{~dB}$ 以上のゲ インで増幅するが, 図 $4(\mathrm{~b})$ の $\mathrm{C} / \mathrm{I}=5 \mathrm{~dB}$ では $18 \mathrm{~dB} \sim 24 \mathrm{~dB}$ 程度 のゲインになり, 図 $4(\mathrm{c})$ の $\mathrm{C} / \mathrm{I}=-25 \mathrm{~dB}$ では $6 \mathrm{~dB} \sim 12 \mathrm{~dB}$ 程度 のゲインになっている。従って, 強い妨害波が受信部に印 加された場合は，ゲインが不足して，低いビット割付值し か与えられないサブキャリアが増加したものと考える。

このようにして，妨害波のサイドローブ特性と受信部の
ゲイン自動制御機能により，図 4 に示すような狭帯域妨害 波の電力レベルに対するサブキャリアのビット割付值特性 が得られたと考える。

次に，ノッチを挿入した場合の妨害波レベルに対するビ ット割付特性を図 5 に示す。ノッチを挿入していない図 4 と比較すると，ノッチの挿入された周波数と帯域幅以外は, ノッチの挿入による影響をほとんど受けていないことが分 かる。

〈2・4〉伝導妨害波イミュニティの測定結果 狭帯域 伝導妨害波に対する高速 PLC モデムの PHY rate 特性を測定 し, その結果を図 6 に示す。図の横軸は, 〈2·3〉節での検 討をもとにして, 全てのサブキャリアの全電カレベル C と 狭帯域妨害波の電力レベル I の比である $\mathrm{C} / \mathrm{I}$ でプロットして いる。縦軸は, 全てのサブキャリアで受信した全体の PHY rate でプロットしている。伝導妨害波は, ノッチの挿入する $14 \mathrm{MHz}, 18 \mathrm{MHz}, 21 \mathrm{MHz}$ および $25 \mathrm{MHz}$ の 4 つの周波数, ノッチ周波数の近傍にある $22 \mathrm{MHz}$ と $26 \mathrm{MHz}$, 及び OFDM 信号の高周波境界である $30 \mathrm{MHz}$ とその境界の外にある $34 \mathrm{MHz}$ にも印加している。(a)はノッチを挿入していない状 態であり，(b)は $14 \mathrm{MHz}, 18 \mathrm{MHz}, 21 \mathrm{MHz}$ および $25 \mathrm{MHz}$ に ノッチを挿入した状態である。

図 7(a)のノッチ未挿入の状態では, OFDM の周波数帯域 内にある 14MHz〜 $26 \mathrm{MHz}$ の周波数では, C/I が $60 \mathrm{~dB}$ から $30 \mathrm{~dB}$ の領域で PHY rate が約 200Mbps と一定であるが, 20dB 以下になると PHY rate が低下し始め, $5 \mathrm{~dB}$ からー15dB では 急激に低下し，-35dB になると, PHY rate がほぼ零になる。 それに対して, OFDM 信号の高周波境界にある $30 \mathrm{MHz}$ とそ の境界外にある $34 \mathrm{MHz}$ では，C/I が $5 \mathrm{~dB}$ まで PHY rate が約 200Mbps と一定であり，0dB 以下になると急激に低下して， $-35 \mathrm{~dB}$ で PHY rate がほぼ零になる。

一方, 図 6(b)のノッチ挿入状態では, 図 6(a)のノッチ未挿 入状態と傾向がかなり異なっている。C/I が $60 \mathrm{~dB}$ から $20 \mathrm{~dB}$ の領域で PHY rate が約 170Mbps と一定であるが, 10dB 以下 になるとノッチを挿入していない $22 \mathrm{MHz}$ と $26 \mathrm{MHz}$ の周波 数における PHY rate が急激に低下し始め, $-30 \mathrm{~dB}$ で PHY rate がほぼ零になる。それに対して, ノッチを挿入した $4 \mathrm{MHz}, 18 \mathrm{MHz}, 21 \mathrm{MHz}$ および $25 \mathrm{MHz}$ の $\mathrm{PHY}$ rate は, 境界 周波数の $30 \mathrm{MHz}$ および境界外の $34 \mathrm{MHz}$ と同じように緩や かな低下傾向を示し，-35dB でも PHY rate が零になってい ない周波数がある。ノッチを挿入していない周波数とは, $\mathrm{C} / \mathrm{I}$ がー $5 \mathrm{~dB}$ から $-15 \mathrm{~dB}$ の領域では, PHY rate が 60Mbps ほ ど大きくなっている。特にノッチ未挿入の(a)とノッチ挿入 の(b)を比較すると, ノッチの挿入する周波数では, $\mathrm{C} / \mathrm{I}$ が - 20dB の領域で, ノッチを挿入したにもかかわらず全体の PHY rate が増加する現象が表れている。例えば，21MHzで はノッチを挿入することにより，40Mbps から 70Mbps に, また， $25 \mathrm{MHz}$ では 55Mbps が 70Mbps にそれぞれ PHY rate が増加している。一方, $\mathrm{C} / \mathrm{I}$ が $20 \mathrm{~dB}$ 以上では, ノッチを挿 入することにより, 全体の PHY rateが 200Mbps から 170Mbps に減少しているため, 上記の現象とは全く逆である。確か 


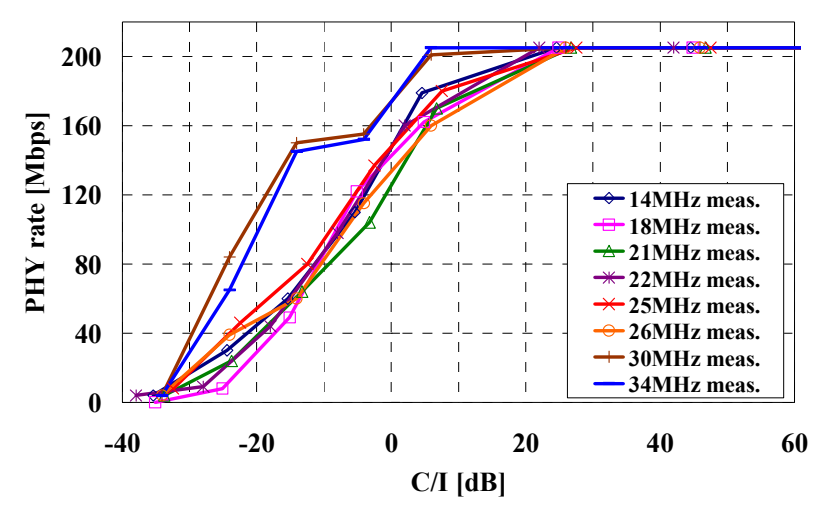

(a) Not inserting notch

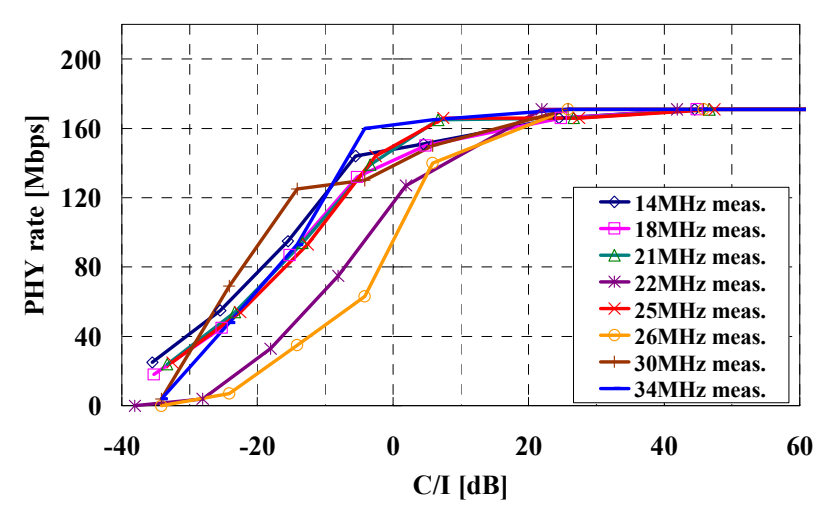

(b) Inserting notch at $14 \mathrm{MHz}, 18 \mathrm{MHz}, 21 \mathrm{MHz}$ and $25 \mathrm{MHz}$

図 6 PLC モデムの伝導妨害波に対する PHY rate 特性測定值

Fig. 6. Measured values of PHY rate characteristics to conducted interference for PLC modem.

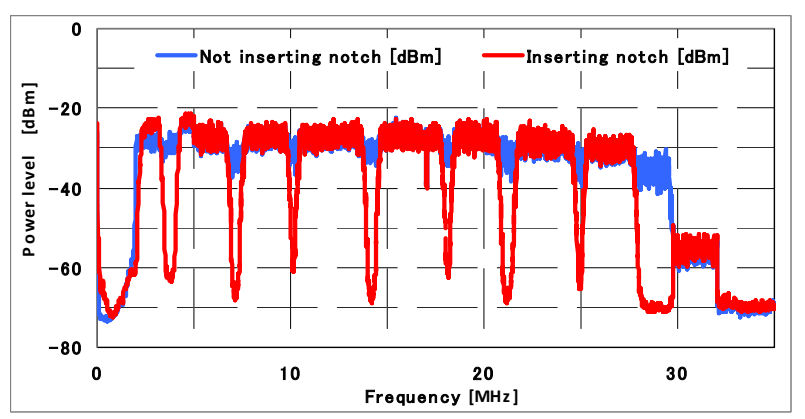

図 7 ノッチ挿入前後の OFDM 信号スペクトルに おける変化

Fig. 7. Spectrum change of OFDM signal when inserting the notch or not.

に，ノッチを挿入することにより，それに相当するサブキ ヤリアが妨害波の影響を受けなくなるため, PHY rate の減 少する程度が少なくなるのは理解できるが, 増加する要因 とはなり得ない。

PHY rate が増加する要因の一つとしては, 高速 PLC モデ ムの OFDM 信号スペクトルが考えられる。OFDM 信号スペ
クトルのノッチ挿入前後における変化を図 7 に示すが, ノ ッチを挿入した場合, ノッチ以外の周波数におけるサブキ ヤリアの電力レベルが増加している。全体の電力をみると, ノッチ挿入前が $2.39 \mathrm{~mW}$ であり, ノッチ挿入後でも $2.33 \mathrm{~mW}$ とほとんど変わっていない。ノッチで使用しなくなったサ ブキャリアの数は, 最大 PHY rate の比 $170 / 200=0.85$ だけ減 少しているため, ノッチ挿入前後でサブキャリアの電力レ ベルが不変であるとすると, 全体の電力レベルは, ノッチ 挿入前の $2.39 \mathrm{~mW} \times 0.85=2.03 \mathrm{~mW}$ になるはずである。ところ が,ノッチ挿入後でも全体の電力レベルが $2.33 \mathrm{~mW}$ である ことから，ノッチ以外のサブキャリアの全電力レベルが $0.3 \mathrm{~mW}$ だけ増加していると言える。このサブキャリアの電 カレベルの増加が, $\mathrm{C} / \mathrm{I}=-20 \mathrm{~dB}$ の前後で, ビット割付值を 増加させる方向に働き, 全体の PHY rate を増加させたので はないかと考える。というのは, $\mathrm{C} / \mathrm{I}=0 \mathrm{~dB}$ でノッチ挿入前後 の PHY rate の変化をみると, $21 \mathrm{MHz}$ では $130 \mathrm{Mbps}$ と変化せ ず, $25 \mathrm{MHz}$ でも $145 \mathrm{Mbps}$ と変化しておらず, $\mathrm{C} / \mathrm{I}=0 \mathrm{~dB}$ では, $0.3 \mathrm{~mW}$ の全電力レベルの増加が, ビット割付值の増加に寄 与しなかったと考えられる。なお, 上記の現象に関する定 量的な検討は, 今後の課題としたい。

ここで，ノッチの挿入による PHY rate の変化を比較する ため, 図 6 を図 8 のように変更した。(a)は, ノッチを挿入 した周波数 $14 \mathrm{MHz}, 18 \mathrm{MHz}, 21 \mathrm{MHz}$ および $25 \mathrm{MHz}$ におけ る PHY rate と C/I の関係をまとめたものであり，(b)は，そ れ以外のノッチを挿入していない周波数 $22 \mathrm{MHz}, 26 \mathrm{MHz}$, $30 \mathrm{MHz}$ および $34 \mathrm{MHz}$ をまとめたものである。図から明らか なように,ノッチを挿入したときの最大伝送速度約 $170 \mathrm{MHz}$ とノッチを挿入しないときの最大伝送速度約 $200 \mathrm{Mbps}$ が異 なるために, ノッチ挿入前後の特性を比較することは難し い。そのため, それぞれの伝送速度を最大の伝送速度で割 って正規化し，\%で表したものを正規化 PHY rateして, 戝 の縦軸にプロットしたものを図 9 に示す。

図 9(a)は，ノッチを挿入した周波数 $14 \mathrm{MHz}, 18 \mathrm{MHz}$, $21 \mathrm{MHz}$ および $25 \mathrm{MHz}$ における結果をまとめたものである。 いずれの周波数でも，ノッチを挿入することにより正規化 PHY rate が上昇しており，18MHz では25\%も改善している。 一方, 同じ正規化 PHY rate を示す C/I も改善しており, $18 \mathrm{MHz}$ では $12 \mathrm{~dB}$ の改善量になっている。これらの改善量 は, OFDM 帯域幅の中心に存在する $14 \mathrm{MHz}, 18 \mathrm{MHz}$ および $21 \mathrm{MHz}$ の周波数では, 同じ傾向を示しているが, OFDM 帯 域幅の端に存在する $25 \mathrm{MHz}$ では, 改善量が少なくなってい る。このノッチによる改善は, 図 4 と図 5 で説明したとお り，ノッチに相当するサブキャリアが妨害波の影響を受け なくなった効果と, また, 図6 から図7 で説明したように, ノッチの挿入によるノッチ以外のサブキャリアにおける電 カレベルの増加による効果が, PHY rate を最大伝送速度で 正規化することによって強調されたためであると考える。 また, 妨害波が PLC 周波数帯域幅の中心に印加した場合は, 妨害波に影響されるサブキャリアの数が多くなるため, 正 規化した PHY rateの改善量が多くなるが，妨害波が PLC 周 


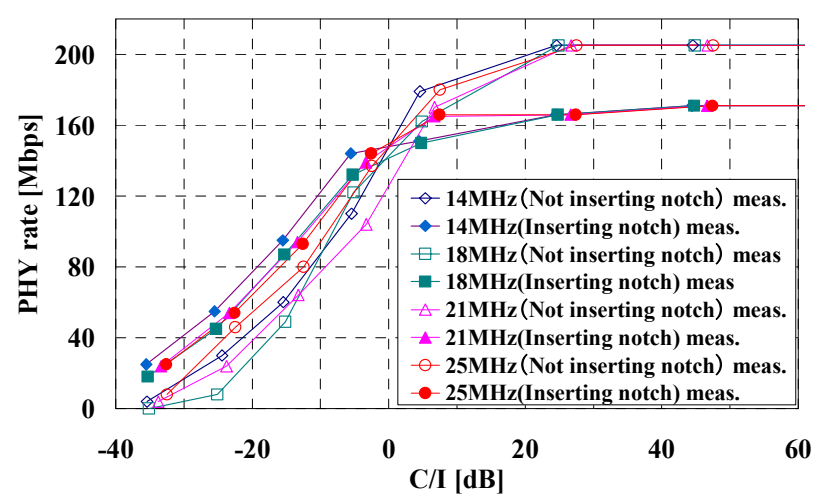

(a) Notch inserting frequency $(14,18,21$ and $25 \mathrm{MHz})$

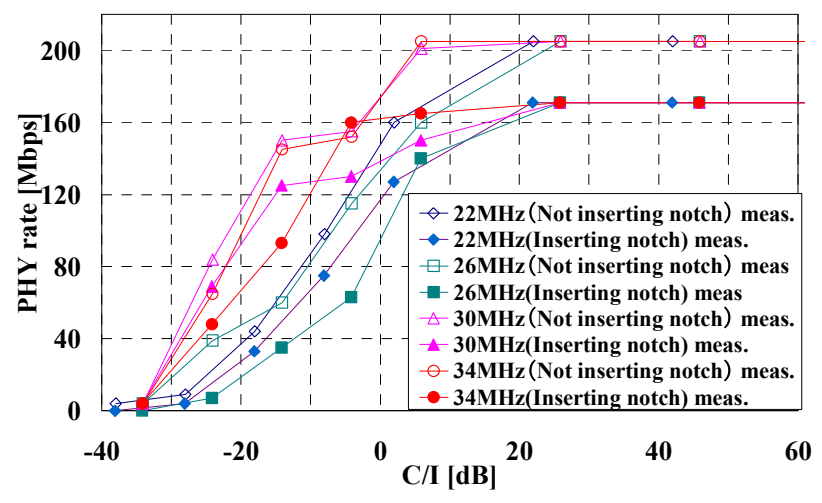

(b) Except for notch inserting frequency $(22,26,30$ and 34MHz)

図 8 ノッチの挿入前後における PHY rate 特性測定值の比較

Fig. 8. Comparison of measured values of PHY rate characteristics between inserting notch and not inserting notch.

波数帯域幅の境界や帯域外に印加した場合は，妨害波に影 響されるサブキャリアの数が少なくなるため, 正規化 PHY rate の改善量が少なくなる。

図 9(b)は, ノッチを挿入していない周波数 $22 \mathrm{MHz}$, $26 \mathrm{MHz}, 30 \mathrm{MHz}$ および $34 \mathrm{MHz}$ における結果をまとめたもの である。 $22 \mathrm{MHz}$ と $30 \mathrm{MHz}$ では，全ての C/I で，ノッチの挿 入前後で正規化 PHY rateがほとんど変化していない。それ に対して, 22MHzでは, ノッチの挿入により正規化 PHY rate が若干低下している。一方, OFDM 帯域幅外の $34 \mathrm{MHz}$ では, $\mathrm{C} / \mathrm{I}$ の值によって，ノッチの挿入効果がプラスに出たり，マ イナスに出たりしている。しかしながら，ノッチを挿入し ていない周波数では，全体として，ノッチの挿入による影 響は僅かであると言える。

以上の結果により，ノッチを挿入すると，その周波数で は正規化 PHY rate が 15〜25\%程度改善し，同じ正規化 PHY rate を示す $\mathrm{C} / \mathrm{I}$ も 10〜 $15 \mathrm{~dB}$ 程度改善することが確認できた。 これらの結果から，本来ノッチは，PLC システムが他の無 線機器に影響を与えないようにすることを目的に適用され た技術であるが，逆に，他の無線機器からのPLC システム に対寸る狭帯域妨害波（特にアマチュア無線からの妨害波） に対しても効果のあることが明らかとなった。

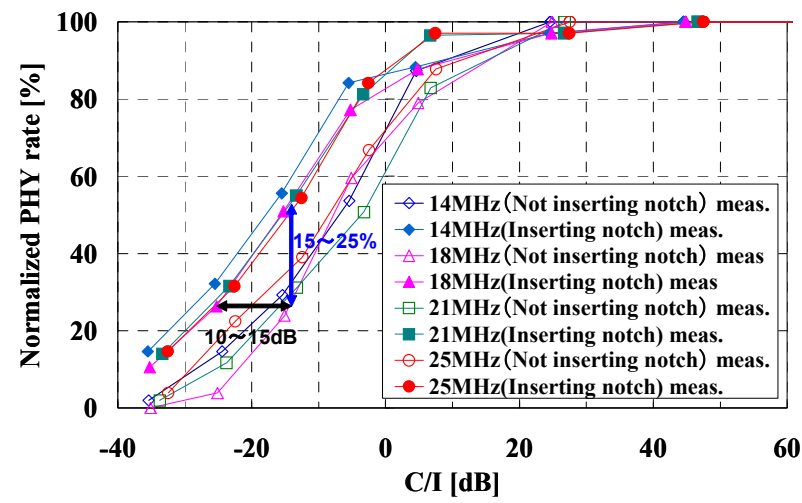

(a) Notch inserting frequency $(14,18,21$ and $25 \mathrm{MHz})$

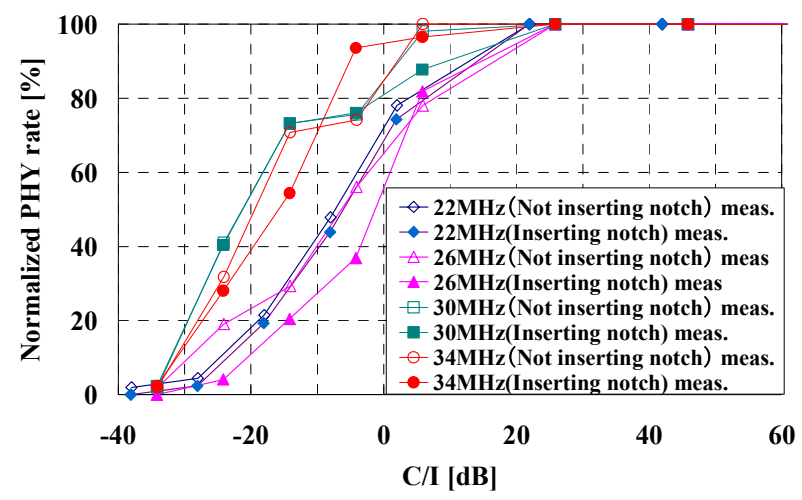

(b) Except for notch inserting frequency $(22,26,30$ and $34 \mathrm{MHz})$

図 9 ノッチ無挿入とノッチ挿入の比較結果 （PHY rate を正規化）

Fig. 9. Comparing inserting notch with not inserting notch for the interference immunity characteristics (Normalized PHY rate).

\section{PLC モデムの伝導妨害波イミュニティ計算}

〈3.1〉伝導妨害波イミュニティのシミュレーション法 本研究で用いた PLC モデムは, 住友電気工業株式会社製 のPLC モデム試作器であり, 変調方式として OFDM 変調方 式が用いられているため, PLC モデムをモデル化し, OFDM

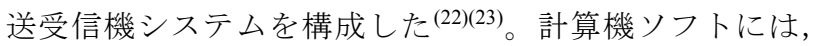
MATLAB/Simulink を用いた。次に電力線伝送路をモデル化 し, 模擬電力線伝送路を構成した。このシミュレーション モデルを用いて，PHY rateを計算した。図 10 にシミュレー ションモデルの構成を示す。まず，送信側では，ランダム な 2 值信号を Encoding ブロックにより符号化し, Mapping ブロックで一次変調し，S/P（Serial/Parallel）により並列信 号にする。そして，IFFT（Inverse Fast Fourier Transform）に より直交変換し，ベースバンド OFDM 信号を生成する。ま た，シンボル間干渉を防ぐために GI（Guard Interval）を挿 入している。一方, 受信側では送信側の逆変換処理を行い, Channel Estimation ブロックにより伝送路等化を行う。等化 手法はロングトレーニングを用いた複素除算により行って いる。 
シミュレーションパラメータを表 2 に示す。使用した PLC モデム試作器では適応変調により, 伝送路の状況に応じて 最適な変調方式を選択し, 通信環境の悪い伝送路において も伝送速度を最大限発揮することができる。従って, シミ ュレーションにおいても，C/I に応じて変調方式を変化させ た。今回の一次変調は 1024, 512, 256, 128, 64, 32, 16QAM (Quadrature Amplitude Modulation: 直交振幅変調) と 8PSK, QPSK, 及びBPSK とし, サブキャリアの数は 1500 本, IFFT 段数を 2048 ，帯域幅を2 30MHz としている。

また，伝送路は ATT（減衰器）と AWGN (Additive White Gaussian Noise）で構成し，狭帯域雑音を模擬したモデルを 挿入している。AWGN は, PLC モデムの送信電力の実測值: $3.7 \mathrm{dBm}$ と一般的な屋内電力線の線路内ノイズの実測值: $-53.3 \mathrm{dBm}$ から理想状態である $\mathrm{Es} / \mathrm{No}=57 \mathrm{~dB}$ と設定した。 また, 実際の屋内電力線では定常状態で平均 $30 \mathrm{~dB}$ の減衰が あるため, 減衰器（ATT: Attenuator）により平均的な減衰量 （30dB）を付加した。更に，今回使用した PLC モデムの信

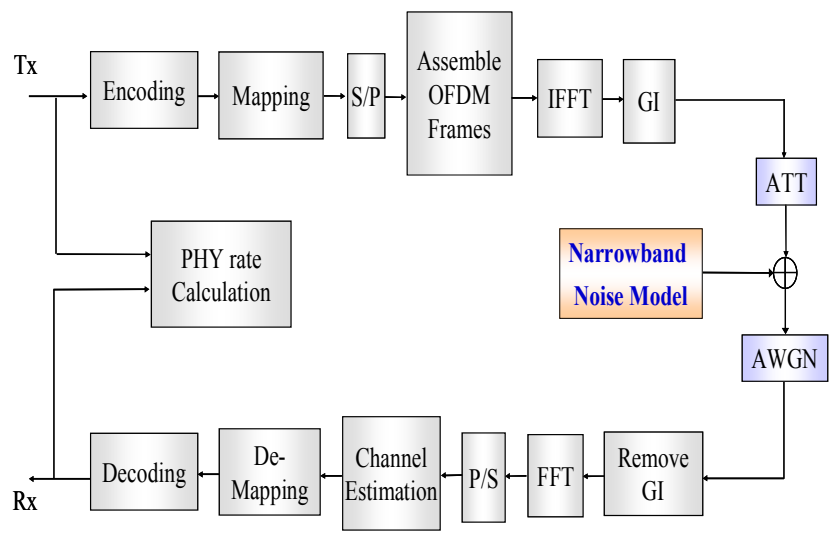

図 10 シミュレーションモデル

Fig. 10. Simulation model of PLC modem.

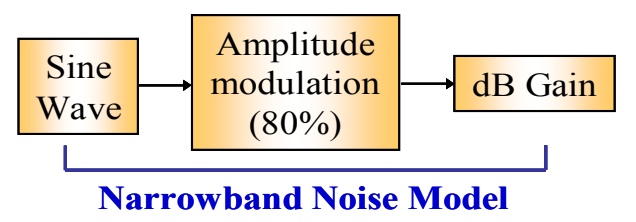

図 11 狭帯域雑音モデル

Fig. 11. Composition of the narrowband noise model.

表 2 OFDM 信号のシミュレーションパラメータ

Table 2. Simulation parameter for OFDM signal using PLC modem.

\begin{tabular}{|c|c|}
\hline Number of Sub-Carriers & 1500 \\
\hline First Modulation & $\begin{array}{c}\text { 1024, 512, 256, 128, 64, 32, } \\
\text { 16QAM, 8PSK, QPSK, BPSK }\end{array}$ \\
\hline Band Width & 28MHz \\
\hline Code Rate & $2 / 3$ \\
\hline Maximum PHY rate & $\begin{array}{c}\text { 200Mbps (Not inserting notch) } \\
\text { 170Mbps (Inserting notch) }\end{array}$ \\
\hline AWGN & SNR=57dB \\
\hline
\end{tabular}

号レベル C (Carrier) は $3.7 \mathrm{dBm}$ であるため, シミュレーシ ヨンでも送信レベルを $3.7 \mathrm{dBm}$ に設定した。

狭帯域雑音モデルを図 11 に示す。測定では妨害波 I (Interference) を SG により印加しており，妨害波のレベル を可変として C/I (Carrier/Interference) に対する PHY rate 特性を測定した。そのため, シミュレーションでも, 図 11 より, 妨害波は変調度 $80 \%$ ・被变調周波数 $1 \mathrm{kHz}$ の振幅変調 波とし, 測定と同様に妨害波のレベルを可変しながら C/I に対する PHY rateを計算した。ここで最大伝送速度は $200 \mathrm{Mbps}$ とし，ノッチを挿入時では $170 \mathrm{Mbps}$ としている。

次に, 図 12 にPLC 信号スペクトルの計算結果を示す。(a) はノッチを挿入しない時の PLC 信号のスペクトルであり, (b)はノッチを挿入した時の PLC 信号のスペクトルであり, (c)はノッチを挿入した状態で, さらに妨害波を印加した時 の PLC 信号のスペクトルである。それぞれ状態における PLC 信号の測定スペクトルを示した図 3 と比較すると, 全 体的に波形が一致していることが確認できる。従って，こ のシミュレーションモデルを用いて, PHY rate の計算を行 っていくことにした。

〈3・2〉 伝導妨害波イミュニティの計算結果 PLC モ デムの狭帯域伝導妨害波に対する PHY rate 特性の計算值 を, 測定值と比較して図 13 に示す。(a)はノッチを挿入しな いときの PHY rate 特性であり, (b)は $14 \mathrm{MHz}, 18 \mathrm{MHz}, 21 \mathrm{MHz}$

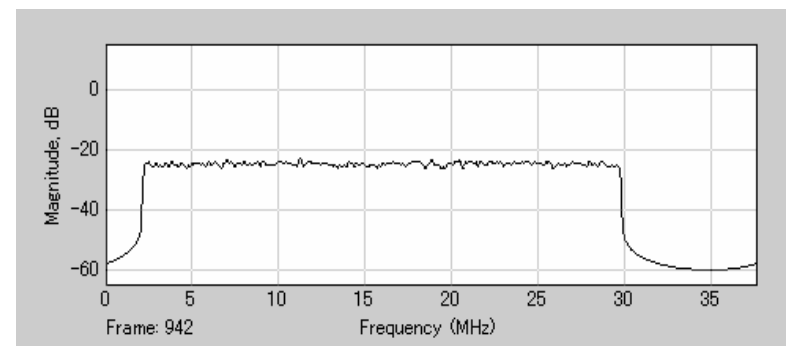

(a) Not inserting notch

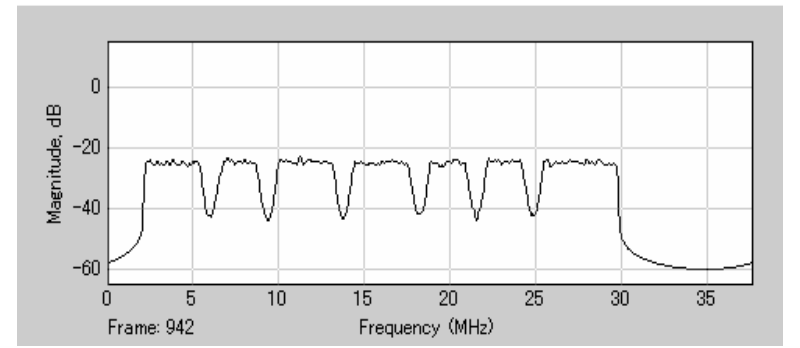

(b) Inserting notch

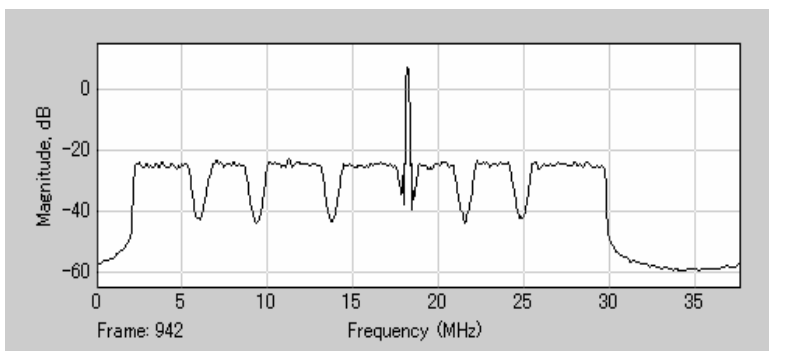

(c) When impressing conducted interference wave at $18 \mathrm{MHz}$

図 12 PLCのOFDM信号スペクトルーシミュレーションー Fig. 12. OFDM signal spectrums of PLC -Simulation-. 


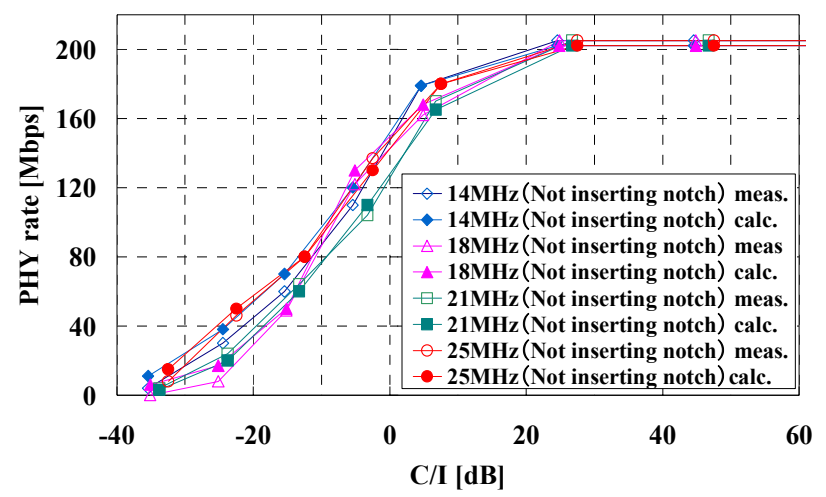

(a) Not inserting notch

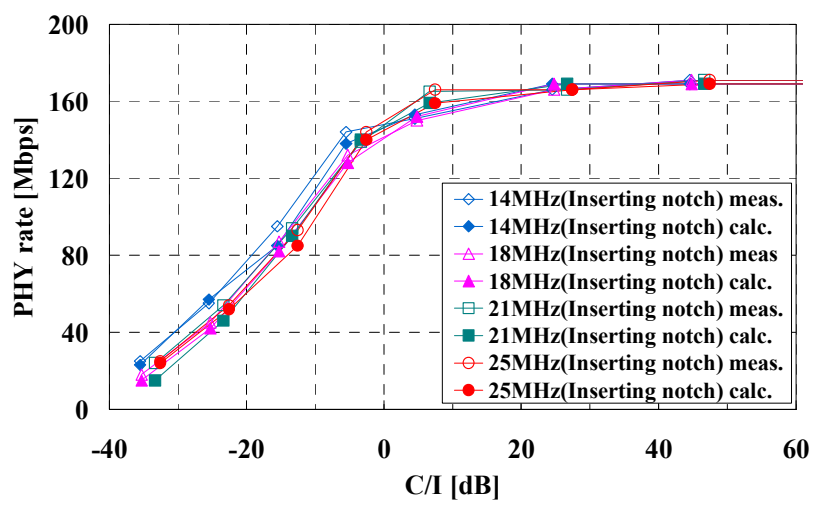

(b) Inserting notch at $14 \mathrm{MHz}, 18 \mathrm{MHz}, 21 \mathrm{MHz}$ and $25 \mathrm{MHz}$

図 13 PLC モデムの伝導妨害波に対する PHY rate 特性計算值

Fig. 13. Calculated values of PHY rate characteristics to conducted interference for PLC modem.

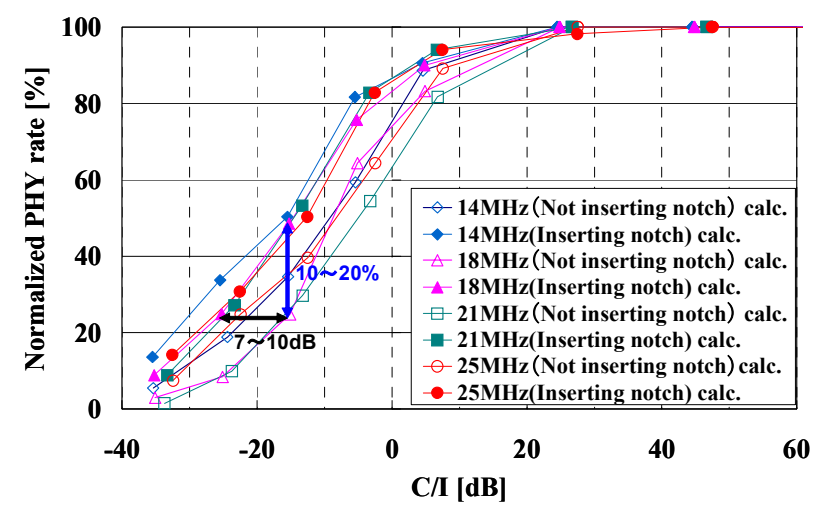

図 14 ノッチ未挿入とノッチ挿入の比較結果

(PHY rate を正規化)

Fig. 14. Comparing inserting notch with not inserting notch for the interference immunity characteristics (Normalized PHY rate).

および25MHzにノッチを挿入したときのPHY rate特性であ る。(a)と(b)の両方とも, PHY rate の計算值は測定值と $2 \mathrm{Mbps}$ 以内で一致しており, C/I の変化に対する PHY rate 測定值の 傾向をほぼ模擬していることが明らかとなった。

図 13(a)のノッチ未挿入と図 13(b)のノッチ挿入における PHY rate の最大值を補正するために, PHY rate 最大值で正規
化した PHY rate を縦軸にプロットした図を図 14 に示す。こ こでは，ノッチを挿入した周波数 $14 \mathrm{MHz}, 18 \mathrm{MHz}, 21 \mathrm{MHz}$ および $25 \mathrm{MHz}$ における計算結果を示しており, 図 9(a)に示 した測定值をシミュレーションしたものである。図 9(a)の測 定值と同様に，ノッチの存在する周波数に妨害波を印加し た場合（例： $\mathrm{C} / \mathrm{I}=-35 \mathrm{~dB}, 18 \mathrm{MHz}$ )，ノッチを挿入しない場 合と比べて正規化 PHY rate が 10〜20\%程度改善し, C/I でも 7〜 10dB 改善されることが計算でも確認できた。これによ り, 狭帯域妨害波を印加した場合でも PHY rateの計算は可 能であり，高速 PLC モデムの狭帯域妨害波に対するイミュ ニティ特性は, 測定ばかりでなくシミュレーションでも計 算可能であることが明らかとなった。

\section{4. むすび}

本研究では, 高速 PLC システムに対するイミュニティ特 性として, 狭帯域伝導妨害波に対する PHY rate 特性を測定 と計算の両面から検討した。同時に, PLC システムからの 放射妨害波対策用に適用されているノッチ技術が, PLC シ ステムのイミュニティ特性に及ぼす効果も検討した。その 結果以下の点が明らかになった。なお, PHY rate の最大值 はノッチを挿入していないとき $200 \mathrm{Mbps}$ であったが，ノッ チを挿入すると $170 \mathrm{Mbps}$ に低下するため, C (キャリアの全 電力）／I（妨害波の電力）に対する PHY rate は，それぞれ の最大值で正規化した正規化 PHY rate（\%值）で記述して いる。

(1) 狭帯域伝導妨害波をノッチの存在する周波数に印 加した場合, その周波数の正規化 PHY rate は, C/I = 30dB 以上では $100 \%$ と全く低下せず, $\mathrm{C} / \mathrm{I}=5 \mathrm{~dB}$ から急激に低下し 始め, $\mathrm{C} / \mathrm{I}=-35 \mathrm{~dB}$ で $10 \%$ 程度になる

(2) 狭帯域伝導妨害波をノッチの存在する周波数に印 加した場合，ノッチの帯域幅だけ妨害波の影響を受けない。 また，ノッチ以外のサブキャリアにおける電力レベルが若 干増大寸るため, $\mathrm{C} / \mathrm{I}=-15 \mathrm{~dB}$ 前後では, ノッチ挿入前より も PHY rateが増加する。そのため, ノッチを挿入しない場 合と比較して，ノッチ周波数の正規化 PHY rate は 15～25\% 程度改善し, 同じ正規化 PHY rate を示す C/I も見かけ上 10 $\sim 15 \mathrm{~dB}$ 程度改善される

( 3 ) MATLAB/Simulink でPHY rateをシミュレーション した結果，測定值と $2 \mathrm{Mbps}$ 以内で一致し，PLC システムの 伝導妨害波イミュニティ特性は測定だけでなく, 計算にお いてもシミュレーションが可能である

今回は, $1 \mathrm{~m}$ 程度の単純な電力線で検討したが，今後はよ り複雑なモデルに対して検討する必要があると考えられ る。また, $\mathrm{C} / \mathrm{I}=-15 \mathrm{~dB}$ 前後でノッチを挿入することにより PHY rate が増加するメカニズムを定量的に検討する必要が ある。

\section{謝 辞}

本研究は, 総務省の SCOPE（戦略的情報通信研究開発制 度）による委託研究に基づく結果である。

(平成 21 年 11 月 27 日受付, 平成 22 年 5 月 17 日再受付) 


\section{文献}

(1) "English Version of ECHONET Specification Ver.2.11", ECHONET Consortium, (2002) (in Japanese)

http://www.echonet.gr.jp/8_kikaku/index.htm

エコーネットコンソーシアム編：「エコーネット規格書 Ver.3.21（日

本語版)」，エコーネットコンソーシアム (2002)

http://www.echonet.gr.jp/8_kikaku/index.htm

(2) HPA (Home Plug Power Line Alliance) home page address: http://www.homeplug.org/home/

(3) High Speed Power Line Communication Promoters' Alliance of Japan (PLC-J): http://www.plc-j.org/

高速電力線通信推進協議会（PLC-J）：http://www.plc-j.org/

(4) IEEJ Investigating R\&D Committee of Home network and EMC (Chairman M. Tokuda): "Home network and EMC, 2. Power Line Communication and EMC", Ohmsha, pp.9-49 (2006) (in Japanese)

電学 ホームネットワークと EMC 調査専門委員会編（委員長 : 徳田 正満）：「ホームネットワークと $\mathrm{EMC} ， 2$ 章 電力線通信と $\mathrm{EMC} 」$, オーム社, pp.9-49 (2006)

(5) IEEJ Investigating R\&D Committee of High-speed Power Line Communication and EMC (Chairman: M. Tokuda): "High-speed Power Line Communication (PLC) and EMC", Ohmsha, pp.1-209 (2007) (in Japanese)

電学 高速電力線通信システムと EMC 調查専門委員会編（委員長： 徳田正満）:「高速電力線通信システム (PLC) と EMC」, オーム社, pp.1-209 (2007)

(6) M. Tokuda : "High speed PLC (Power Line Communication)", The Journal of IEICE, Vol.88, No.3, pp.170-175 (2005) (in Japanese)

徳田正満：「高速パワーラインコミュニケーション」, 信学会誌, Vol.88, No.3, pp.170-175 (2005)

( 7 ) M. Tokuda : "Technical Trends in High-Speed Power Line Communication", IEICE Trans. Communications, Vol.E88-B, No.8, pp.3115-3120 (2005-8)

(8) S. Tsuzuki : "High-Speed Power-Line Communication and its Application to a Localization System", (INVITED PAPER), IEICE Trans. Fundamentals of Electronics, Communications and Computer Sciences, Special Section on Wide Band Systems, Vol.E89-A, No.11, pp.3006-3012 (2006)

(9) S. Tsuzuki : "Home Network and Sensor Network by Power-Line Communications", (INVITED PAPER), Technical Report of IEICE, Vol.105, No.176, WBS2005-20, pp.67-72 (2005) (in Japanese) 都築伸二 :「[招待講演]電力線通信によるホームネットワーク・セ ンサネットワーク」，信学技報, Vol.105, No.176, WBS2005-20, pp.67-72 (2005)

(10) 高速電力線搬送通信に関する研究会：「高速電力線搬送通信に関す る研究会報告書」, 総務省総合通信基盤局電波部電波環境課 (2005) http://www.soumu.go.jp/s-news/2005/051226_6.html

(11) 情報通信審議会情報通信技術分科会 CISPR 委員会：「高速電力線搬 送通信設備に係る許容值及び測定法」について答申，総務省総合通 信基盤局電波部電波環境課 (2006) http://www.soumu.go.jp/s-news/2006/060629 3.htm

（12）官報，平成 18 年 10 月 4 日付（号外 第 227 号） http://kanpou.npb.go.jp/20061004/20061004g00227/20061004g00227000 0f.html

(13) K. Miyoshi, N. Kuwabara, Y. Akiyama, and H. Yamane : "Calculation of Radiating Magnetic Field from Indoor AC Mains Cable Using Four Port Network", Technical Report of IEICE, EMCJ2004-123 (2005) (in Japanese) 三吉金吾・桑原信夫・秋山佳春・山根 宏 :「屋内配電線から放射さ れる磁界強度の 4 ポート回路網を用いた解析」，信学技報，Vol.104， EMCJ2004-123 (2005)

(14) D. Hirata, N. Kuwabara, and Y. Akiyama : "Investigation of Influence by Power Line Communication Signals to Amplitude Modulation Signals", Technical Report of IEICE, EMCJ2005-65 (2005) (in Japanese) 平田大介・桑原信夫・秋山佳春 : 「電力線通信信号が AM 信号に及ぼ 寸影響の検討」，信学技報, Vol.105, EMCJ2005-65 (2005)

(15) A. Mori, Y. Watanabe, M. Tokuda, and K. Kawamoto : "Transmission Characteristics of an OFDM signal for Power Line Communication System with High Bit Rate", IEEJ Trans. EIS, Vol.126, No.7, pp.810-817 (2006) (in Japanese)

森晃・渡邊陽介・徳田正満・河本康二：「高速電力線通信システ ムに対する OFDM信号の伝送特性」, 電学論C, 126, 7, pp.810-817 (2006)
(16) Y. Watanabe, M. Tokuda, and M. Maki : "Calculation of LCL (Longitudinal Conversion Loss) and leaked magnetic field in power line with branch for PLC system", IEICE Trans., Vol.J90-B, No.6, pp.601-611 (2007) (in Japanese)

渡邊陽介・徳田正満・牧 昌弘: 「分岐を有する電力線の対地平衡度 と漏えい磁界の計算」, 信学論, J90-B, 6, pp.601-611 (2007)

(17) H. Koga and N. Kodama : "A Study on Performmance of Wavelet OFDM in Power Line", IEEJ Trans. EIS, Vol.128, No.7, pp.1081-1086 (2008) (in Japanese)

古賀久雄・ 児玉宣貴 : 「電力線伝送路における Wavelet OFDM 特性に ついての一検討」, 電学論 C, 128, 7, pp.1081-1086 (2006)

(18) T. Inada and Y. Namba : "Analytical Modeling of Transmission Characteristics of Distribution Line for High-Speed Power-Line Communication", Matsushita Electric Works Analysis Center Co., Ltd. Vol.53, No.4, pp.46-51 (2005) (in Japanese)

稲田 勉・難波嘉彦:「高速電力線通信における配電線の伝送特性解 析モデル」，松下電工技報, Vol.53, No.4, pp.46-51 (2005)

(19) IEC Standard IEC 61000-4-6 : "Electromagnetic compatibility (EMC) Part 4-6: Testing and measurement techniques - Immunity to conducted disturbances, induced by radio-frequency fields", Ed.2.2 (2006) (in Japanese) IEC 規格 IEC 61000-4-6:「無線周波電磁界で誘導された伝導妨害に 対するイミュニティ試験」，第 2.2 版 (2006)

(20) IEC tandard IEC 61000-4-3 : "Electromagnetic compatibility (EMC) Part 4-3: Testing and measurement techniques - Radiated, radio-frequency, electromagnetic field immunity test", Ed.3. (2006) (in Japanese) IEC 規格 IEC 61000-4-3 :「放射無線周波電磁界イミュニティ試験」, 第 3.0 版 (2006)

(21) R. Nilson, F. Sjoberg, and J. P. LeBlanc : "A Rank-Reduced LMMSE Canceller for Narrowband Interference Suppression in OFDM-Based Systems", IEEE Trans. Communications, Vol.51, No.12, pp.2126-2140 (2003)

(22) Triceps Planning Department : "MATLAB program case explanation for digital communication system", Triceps Co. (2000) (in Japanese) トリケップス企画部編：「ディジタル通信システムのための MATLAB プログラム事例解説」，（株）トリケップス (2000)

(23) Triceps Planning Department : "The BER characteristic evaluation of the OFDM modulation and demodulation system", Triceps Co. 2005 (in Japanese)

トリケップス企画部編：「OFDM 変復調システムの BER 特性評価」, 株式会社トリケップス (2005)

德 田 正満 (正員) 1944 年 10 月 19 日生。1 967 年 3 月北

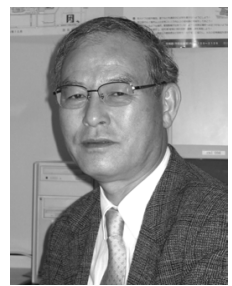
海道大学卒業。1969 年同大大学院修士課程修 了。同年日本電信電話公社に入社。以来, 通信 用ケーブル，光ファイバーケーブル伝送特性測 定法，及び通信装置の EMC 等の研究に従事。 1996 年九工大・工・電気工教授。2001 年 4 月 武蔵工大・工・電子通信工教授。現在, 東京都 市大学 (武蔵工業大学が校名変更) 知識工学部 (工学部から分離) 情報ネットワーク工学科（電子通信工学科から 分離）教授。1991 年から 1993 年まで, 電子情報通信学会環境電磁 工学研究会委員長。2006 年 9 月より IEC / TC77 国際議長。IEEE フ エロー。工博。

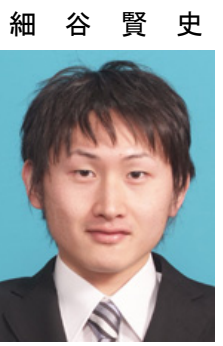

（非会員） 1984 年生。 2007 年 3 月武蔵工業大 学工学部電子通信工学科卒, 2009 年 4 月同武蔵 工業大学大学院工学研究科修士課程電気工学 専攻入学修了, 電力線通信システムに関する研 究に従事。2 2009 年 4 月 NTT 東日本に就職。 


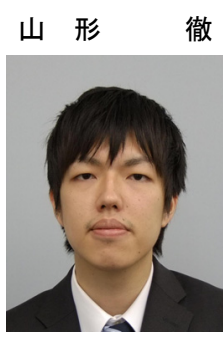

松尾尚 (非会員) 1972 年 5 月 3 日生。1996 年 3 月京 学工学部電子通信工学科卒, 同年 4 月同大学大 学院工学研究科修士課程電気工学専攻入学, 在 学中。現在, 電力線通信システムに関する研究 に従事。

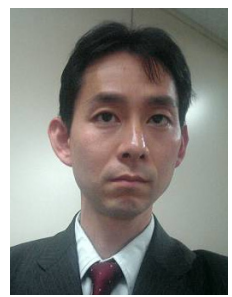
都大学卒業。同年住友電気工業（株）に入社。 以来, 電力ケーブルの研究, 光ファイバーの製 造，高速電力線搬送通信の開発に従事。 